\title{
Kinetically Stable Silver Complexes of Calixspherands
}

\author{
Wouter I. Iwema Bakker, Willem Verboom and David N. Reinhoudt* \\ Laboratory of Organic Chemistry, University of Twente, PO Box 217, 7500 AE Enschede, The Netherlands
} Calixspherands 1 and 2 form kinetically stable complexes with $\mathrm{Ag}^{+}$, in $\mathrm{CDCl}_{3}$ saturated with $\mathrm{D}_{2} \mathrm{O}$, with half-lives of
decomplexation of 51 and $131 \mathrm{~h}$, respectively.

We have recently shown that calixspherands 1 and 2 form kinetically very stable complexes with the alkali metal ions $\mathrm{Na}^{+}, \mathrm{K}^{+}$, and $\mathrm{Rb}^{+}$. The $\mathrm{Rb}^{+}$complexes have decomplexation half-lives, in $\mathrm{CDCl}_{3}$ saturated with $\mathrm{D}_{2} \mathrm{O}$, of $139 \mathrm{~h}$ and $180 \mathrm{~d}$, respectively, whereas the complexes with $\mathrm{Na}^{+}$and $\mathrm{K}^{+}$have decomplexation half-lives of several years. ${ }^{1}$ The cavity of the calixspherands with its size of $c a .2 .2 \AA$, as calculated from the crystal structure of $[3 . \mathrm{Na}]^{+}, 2$ is complementary to $\mathrm{Ag}^{+}(2.52$ $\AA)$, and is highly shielded from solvent molecules. Hence the calixspherands should also be able to form kinetically stable complexes with silver, although they lack the soft donor atoms sulfur and nitrogen which are preferred for the complexation of the soft silver cation. 3,4

Kinetically stable complexes of silver-111 (a $\beta$-emitter; $E_{\max }$ $1.04 \mathrm{MeV}$ ) may be used in cancer radioimmunotherapy as it produces little (7\%) $\gamma$-radiation, and has a physical half-life of $179 \mathrm{~h}$. The decay profile ensures that tissue penetration is restricted to $c a .1 .1 \mathrm{~mm}^{5}$ In this communication the kinetic stability of silver complexes of calixspherands 1 and 2 is discussed.

Complexation of the free 1 and $2^{1}$ with silver triflate in chloroform-methanol $1: 1$ afforded the silver complexes in almost quantitative yields. Complexation was confirmed by fast atom bombardment mass spectrometry and by high field shift in the ${ }^{1} \mathrm{H}$ NMR spectra for the methoxy group, which is

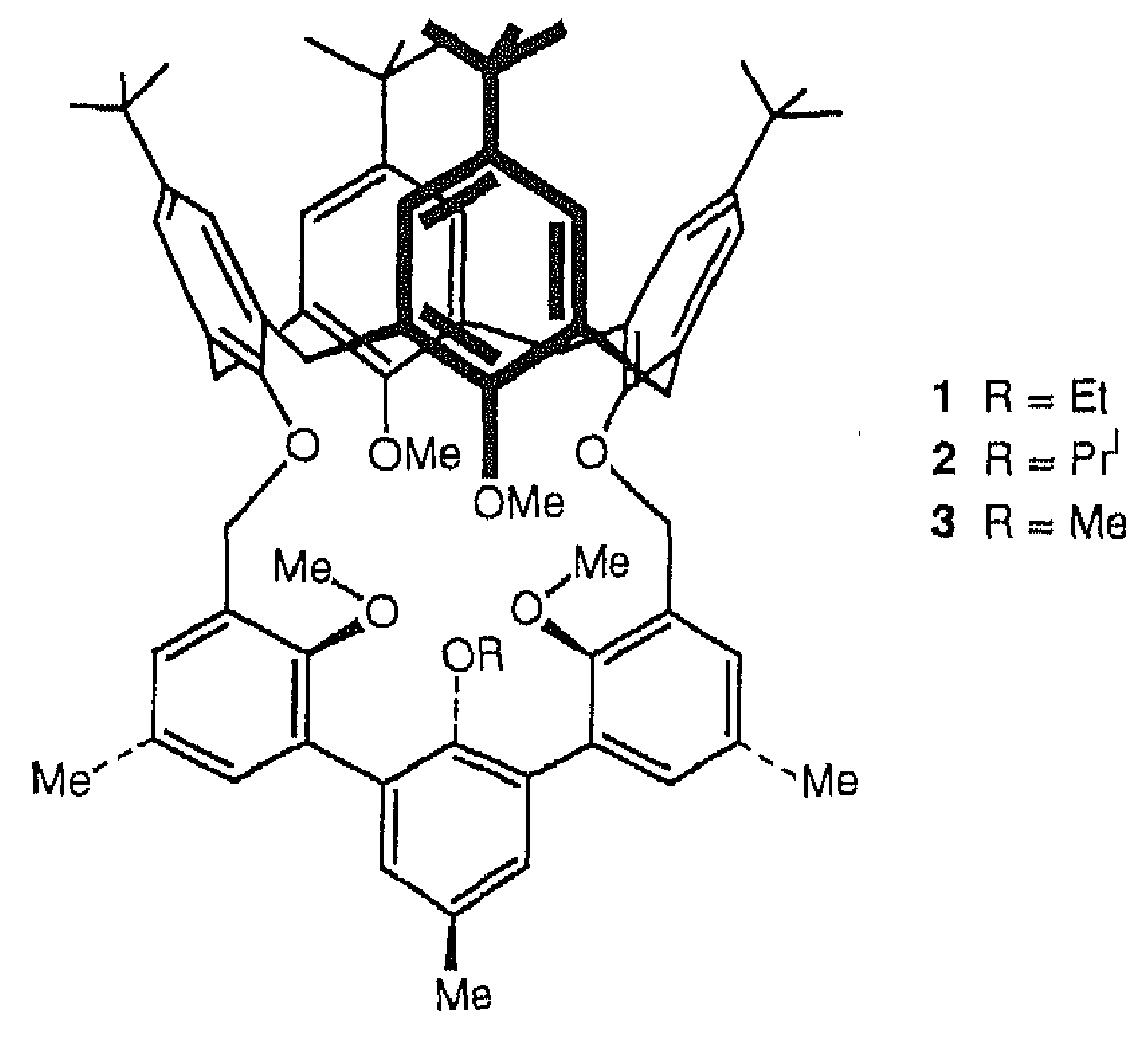

Table 1 Decomplexation rate constants $\left(k_{\mathrm{d}}\right)$ for the silver complexes of calixspherands 1 and 2 in $\mathrm{CDCl}_{3}$ saturated with $\mathrm{D}_{2} \mathrm{O}$

\begin{tabular}{lllll}
\hline Host & $T /{ }^{\circ} \mathrm{C}$ & $k_{\mathrm{d}} / \mathrm{s}^{-1}$ & $\begin{array}{l}\Delta H / \\
\mathrm{kJ} \mathrm{mol}^{-1}\end{array}$ & $\begin{array}{c}-T \Delta S^{\mathrm{I} /} \\
\mathrm{kJ} \mathrm{mol}\end{array}$ \\
\hline \multirow{4}{*}{1} & 40 & $3.3 \times 10^{-5}$ & & \\
& 47 & $6.4 \times 10^{-5}$ & 105 & -1.3 \\
& 55 & $2.2 \times 10^{-4}$ & & \\
\hline \multirow{4}{*}{2} & $25^{b}$ & $3.8 \times 10^{-6}$ & & \\
& 45 & $1.3 \times 10^{-5}$ & & 20.1 \\
& 50 & $2.8 \times 10^{-5}$ & 86 & \\
\hline
\end{tabular}

a $25^{\circ} \mathrm{C} .{ }^{b}$ Extrapolated to $25^{\circ} \mathrm{C}$. situated in the cavity of the calix[4]arene moiety, from $8 \mathrm{ca} .3$ (free ligand) to $\mathrm{ca} .0 . \dagger$

The determination of the decomplexation rate constant of $[1 \cdot \mathrm{Ag}]^{+}$and $[2 \cdot \mathrm{Ag}]^{+}$, which determines the kinetic stability, was performed as described for the spherands by Cram and Lein $^{6}$ and as used for the alkali metal complexes of the calixspherands. ${ }^{1,2}$ In this method, a time course analysis of the exchange of $\mathrm{Ag}^{+}$from a non-deuteriated ligand to a partially deuteriated ligand was followed by ${ }^{1} \mathrm{H}$ NMR spectroscopy. ${ }^{6}$ Decomplexation rate constants $\left(k_{\mathrm{d}}\right)$ at $25^{\circ} \mathrm{C}$ for the silver complexes of 1 and 2 were calculated from the obtained rates of decomplexation at higher temperatures by an Eyring plot. The results are summarized in Table 1 . The decomplexation rates are the lowest reported for $\mathrm{Ag}^{+}$complex, ${ }^{7}$ e.g. the $\mathrm{Ag}^{+}$ complex of cryptand-[2.2.1] has a $k_{\mathrm{d}}$ of $5.6 \times 10^{-4} \mathrm{~s}^{-1}$ in $\mathrm{Me}_{2} \mathrm{SO}$ at $25^{\circ} \mathrm{C} .{ }^{8}$ Our results show that kinetically stable silver complexes are formed by the calixspherands. Half-lives for decomplexation at $25^{\circ} \mathrm{C}$ were calculated from the decomplexation rate constants $\left[t_{\frac{1}{2}}^{\frac{1}{2}}=\ln \left(2 / k_{\mathrm{c}}\right)\right]$ and are $50.9 \mathrm{~h}$ for 1 and $131 \mathrm{~h}$ for 2 . These half-lives are shorter than those for decomplexation of rubidium. The results obtained for 1 and 2 indicate that, although the size-fit between the cavity size and the ionic radius of silver is good and the cavity is highly shielded from solvent molecules, the interaction between the oxygen donor atoms and silver probably is too weak to obtain silver complexes which are sufficiently stable for in vivo use. Furthermore, the longer half-life for decomplexation of $[2 . \mathrm{Ag}]+$ compared with that of $[1 . \mathrm{Ag}]+$ shows that, just as for alkali metal ion complexes, the kinetic stability of the complexes is increased when the shielding of the cavity is increased.

The results described in this communication show that kinetically stable silver complexes are formed with ligands, which have only oxygen donor atoms and a highly shielded cavity. The substitution of one or more oxygen atoms for sulfur atoms in the calixspherands in order to obtain ligands for silver which may be used for practical application in vivo, for example in radioimmunotherapy, is currently under investigation.

We thank the Technology Foundation (STW), Technical Science Branch of the Netherlands Organization for Scientific Research (NWO) for financial support and Dr J. P. M. van Duynhoven and $J$. M. Visser for assistance in recording ${ }^{1} \mathrm{H}$ NMR spectra.

Received, 31st August 1993; Com. 3/05216H

\section{Footnotes}

+1 : $\mathrm{mp}>225^{\circ} \mathrm{C}$ decomp.; ${ }^{1} \mathrm{H}$ NMR $\left(\mathrm{CDCl}_{3}\right) \delta 7.34$ (s, $\left.2 \mathrm{H}\right), 7.33$ (s, 2 H), $7.20(\mathrm{~d}, 2 \mathrm{H}, J 2.3 \mathrm{~Hz}), 7.18$ (br s, $2 \mathrm{H}), 7.02(\mathrm{br} \mathrm{s}, 2 \mathrm{H}), 6.91(\mathrm{~d}, 2$ $\mathrm{H}, J 2.3 \mathrm{~Hz}), 6.80(\mathrm{~s}, 2 \mathrm{H}), 6.09$ and $4.19(\mathrm{ABq}, 4 \mathrm{H}, J 11.1 \mathrm{~Hz}), 4.70$ and $3.71(\mathrm{ABq}, 4 \mathrm{H}, J 12.5 \mathrm{~Hz}), 4.37(\mathrm{~s}, 3 \mathrm{H}), 3.76$ and $3.17(\mathrm{ABq}, 4$ $\mathrm{H}, J 14.9 \mathrm{~Hz}), 3.67(\mathrm{~s}, 6 \mathrm{H}), 2.50(\mathrm{~s}, 3 \mathrm{H}), 2.38(\mathrm{~s}, 6 \mathrm{H}), 1.96(\mathrm{q}, 2 \mathrm{H}, J$ $7.0 \mathrm{~Hz}), 1.31$ and $1.17(\mathrm{~s}, 9 \mathrm{H}), 1.06(\mathrm{~s}, 18 \mathrm{H}),-0.02(\mathrm{~s}, 3 \mathrm{H}),-0.31(\mathrm{t}$, $3 \mathrm{H}, J 7.0 \mathrm{~Hz}) ; \mathrm{MS} m / z(\mathrm{FAB}) 1185.5(\mathbf{1} \cdot \mathrm{Ag})^{+}$. Satisfactory elemental analysis. 2: $\mathrm{mp}>240^{\circ} \mathrm{C}$ decomp.; ${ }^{1} \mathrm{H} \mathrm{NMR}\left(\mathrm{CDCl}_{3}\right) \& 7.37(\mathrm{~s}, 2 \mathrm{H})$, 7.34 (s, $2 \mathrm{H}), 7.24$ (d, $2 \mathrm{H}, J 2.3 \mathrm{~Hz}), 7.19$ (br s, $2 \mathrm{H}$ ), 7.00 (brs, $2 \mathrm{H}$ ), $6.96(\mathrm{~d}, 2 \mathrm{H}, J 2.3 \mathrm{~Hz}), 6.88(\mathrm{~s}, 2 \mathrm{H}), 5.99$ and $4.19(\mathrm{ABq}, 4 \mathrm{H}, J 10.8$ $\mathrm{Hz}), 4.71$ and $3.74(\mathrm{ABq}, 4 \mathrm{H}, J 12.5 \mathrm{~Hz}), 4.30(\mathrm{~s}, 3 \mathrm{H}), 3.91$ and 3.31 
(ABq, 4 H, J 14.9 Hz), 3.69 (s, 6 H), 2.73-2.63 (m, $1 \mathrm{H}), 2.52(\mathrm{~s}, 3 \mathrm{H})$, $2.36(\mathrm{~s}, 6 \mathrm{H}), 1.30(\mathrm{~s}, 9 \mathrm{H}), 1.20(\mathrm{~s}, 9 \mathrm{H}), 1.08(\mathrm{~s}, 18 \mathrm{H}), 0.04(\mathrm{~s}, 3 \mathrm{H})$, $-0.38(\mathrm{~d}, 6 \mathrm{H}, J 6.2 \mathrm{~Hz}) ; \mathrm{MS} m / 2(\mathrm{FAB}) 1199.6(2 \cdot \mathrm{Ag})^{+}$.

\section{References}

1 W. I. Iwema Bakker, M. Haas, C. Khoo-Beattie, R. Ostaszewski, S. M. Franken, H. J, den Hertog, Jr., W. Verboom, D. de Zeeuw, S. Harkema and D. N. Reinhoudt, J. Am. Chem. Soc, in the press. 2 P. J. Dijkstra, J. A. J. Brunink, K.-E. Bugge, D. N. Reinhoudt, S. Harkema, R. Ungaro, F. Ugozzoli and E. Ghidini, J. Am. Chem. Soc., 1989, 111, 7567.

3 R. G. Pearson, J. Am. Chem. Soc., 1963, 85, 3533.
4 R. L. Bruening, R. M. Izatt and J. S. Bradshaw, in Cation Binding by Macrocycles, ed. Y. Inoue and G. W. Gokel, Marcel Dekker, N.Y., 1990; p. 111.

5 D. Parker, Chem. Soc. Rev., 1990, 19, 271; A. S. Craig, R. Kataky, D. Parker, H. Adams, N. Bailey and H. Schneider, J. Chem. Soc., Chem. Commun., 1989, 1870; A. S. Craig, R. Kataky, R. C. Matthews, D. Parker, G. Ferguson, A. Lough, H. Adams, N. Bailey and H. Schneider, J. Chem. Soc., Perkin Trans. 2, 1990, 1523.

6 D. J. Cram and G. M. Lein, J. Am. Chem. Soc., 1985, 107, 3657.

7 R. M. Izatt, K. Pawlak, J. S. Bradshaw and R. L. Bruening, Chem. Rev., 1991, 91, 1721.

8. B. G. Cox, J. Garcia-Rosas, H. Schneider and Ng. van Truong, Inorg. Chem., 1986, 25, 1165. 